\title{
ВМІСТ ЛАКТАТДЕГІДРОГЕНАЗИ В ТКАНИННИХ ЕКСТРАКТАХ ФУНКЦІОНАЛЬНОГО ШАРУ ЕНДОМЕТРІЯ ЗА РІЗНИХ СТАДІЙ СТАТЕВОГО ЦИКЛУ ТА ПРИ АНАФРОДИЗІЇ КОРІВ
}

\author{
Бондаренко Ірина Вікторівна \\ кандидат ветеринарних наук, доцент \\ Сумський національний аграрний університет (м. Суми, Україна) \\ ORCID: 0000-0002-1019-3446 \\ iryna.bondarenko@snau.edu.ua
}

\begin{abstract}
Рентабельність молочного тваринництва залежить від ефективного впровадження й планомірного застосування сучасних репродуктивних методів корекції, які дозволяють суттєво підвищити кількість поголів'я, покращити генетичний потенціал високопродуктивних тварин, та спланувати їх відтворення (Makrigiannakis A, 2021). Неодмінна умова сталої рентабельності молочного тваринництва - апробація та практичне застосування сучасних методів стимуляції та корекції. Саме це забезпечить зростання відсотку запліднених самок, мінімізує кількість абортів й буде сприяти отриманню здорового приплоду (Riordan, N. H. 2018; Khamytova L. F. 2015).

Репродуктивний потенціал залежить від повноцінної нейрогуморальної регуляції та інтенсивності обмінних процесів організму. Оптимальний гормональний статус організму корів, зумовлює ффізіологію обмінну речовин, сприяє фрункціональній активності геніталій, що в свою чергу забезпечує отримання найкращих показників відтворення. (Granot I, 2012) Саме через це, навіть незначні санітарно-гігієнічні помилки утримання та експлуатації корів, обумовлюють погіршення показників відтворення. Фізіологія запліднення, розвитку зиготи, й вагітності, передусім залежать від збалансованості гормонального фрону материнського організму (Sheremeta VI, 2011)..

Корекція відтворної функції корів полягає у створенні комфортних умов для фрізіологічного існування організму протягом репродуктивного періоду, та передбачає застосування біологічно-активних речовин, тканинних, гормональних препаратів, та біотехнологічних прийомів, що посилюють та активують ендокринний та метаболічний профріль організму, покращують обмінні процеси репродуктивних органів (Tuckerman E, 2010). Необхідність стимуляції та корекції репродуктивного потенціалу корів, змушує фрахівців до пошуку та широкого вжитку біологічно активних речовин, тканинних препаратів та біотехнологічних заходів, які активують метаболічну і ендокринну системи, та підсилюють обмінні процеси статевих органів (Hara R. 2002.). Тому питання корекції та стимуляції репродуктивної здатності лишаються актуальними дотепер і потребують комплексного вивчення й аналізу морфо-фрізіологічних особливостей підготовки статевої системи корів до запліднення, імплантації та вагітноcmi (Tvarynnytstvo ta veterynariya 2018).
\end{abstract}

Для результативного застосування стимулюючих біологічно-активних засобів на репродуктивну фрункцію корів протягом різних стадій статевого циклу, неодмінним є вивчення механізмів впливу та взаємозв'язок останніх з різними ланками метаболічних процесів (Edwards R.G. 2006). При вирішенні вищевказаних питань, першорядна увага приділяється стану ендометрія за вагітності корів, тоді як сам процес ремоделювання функціонального шару ендометрія протягом стадії збудження, що забезпечує фрізіологію імплантації та вагітності, лишається поза увагою. (Bondarenko I. V. 2016)

Функціональний шар ендометрія має високу ферментативну активність, в тому числі й лактатдегідрогеназну. Зміни вмісту останньої, є інформативними, а сама ЛДГ відносяться до маркерів деградації сполучного матриксу, оскільки доведена роль фрерментів, в тому числі й лактатдегідрогенази (ЛДГ) за розвитку патології статевих органів. Так, за перерозподілу типів обміну тканини, та при зниженні диференціювання клітин, активність лактатдегідрогенази зростає. За пошкодження клітин, вищевказаний фермент потрапляє в кров, тому може використовуватися в якості додаткового діагностичного показника та контролю лікування (Zhou A. G. 2018).

У cтатmі наведено й проаналізовано результати дослідження концентрації лактатдегідрогенази в тканинних екстрактах функціонального шару ендометрія корів за різних стадій статевого циклу та за анафродизії.

Встановлено, що під час еструсу відбувається найактивніша фрізіологічна активізація обміну речовин, що супроводжується зростанням концентрації лактатдегідрогенази в екстрактах тканин ендометрія, порівняно з проеструсом та за розквіту жовтого тіла. У тварин, що перехворіли на ендометрит та затримку посліду, й знаходились в стані анафродизії, концентрація лактатдегідрогенази у тканинних екстрактах фрунціонального шару ендометрія наближається до мінімальних значень.

Ключові слова: корови, статевий цикл, лактатдегідрогеназа, анафродизія,ендометрій, тканинні екстракти.

DOI https://doi.org/10.32845/bsnau.vet.2021.2.3

\section{Вступ}

Розмноження великої рогатої худоби - це складний комплекс біолого-технологічних процесів, що залежать від взаємодії зовнішніх та внутрішніх фракторів. Стан відтворення корів - $є$ основною проблемою молочного тваринництва й характеризує економічну ефективність скотарства взагалі. Оцінка відтворення в господарстві здійснюється за багатьма критеріями, до яких належать: тривалість вагітності, сухостійного, міжотельного і сервіс-періоду періодів. Загальновідомо й те, що високі показники відтворення не тільки основа для відтворення, а й передумова для максимальної молочної продуктивності корів та їх тривалого репродуктивного існування (Sheremeta V. I. 2009). 
Фахівці молочного скотарства та науковці все частіше звертають увагу на санітарно-гігієнічні норми утримання корів, оскільки порушення останніх негативно впливає на відтворну здатність. Для інтенсифікації відтворного потенціалу корів, розробляються та використовуються різноманітні нейротропно-метаболічні засоби. Такі засоби активують гіпоталамо-гіпофрізарно-яєчниково-матковіі зв'язки за рахунок інтенсифікації обмінних процесів нервових з'єднань протягом стадії збудження (Shtapenko O. V. 2018).

Загальновідомо, що нервова система має важливу роль в регуляції відтворної функції, а розлади утримання й годівлі, негативно впливаючи на нейрогуморальну регуляцію, викликають стійкі порушення репродуктивної системи та непліддя. Репродуктивна функція представлена саморегульованою та повторюваною сталим порядком зворотною аферентацією, (нервові та гуморальні ланцюги), яка забезпечує ефрективність пристосувального та адаптаційного ефекту. Саме таким чином досягається головна біологічна мета репродуктивної системи - збереження виду. Зміни ендометрія на біохімічному та морфологічному рівні протягом різних стадій статевого циклу, супроводжуються активною фрізіологічною перебудовою (Bezverha LM. 2012).

Регуляція репродуктивного потенціалу самок, представлена складною нейрогуморальною системою, яка являє собою шестиступеневу ієрархічну модель, що об'єднує та взаємно зв'язує зовнішні фактори оточуючого середовища та внутрішній стан організму, центральну нервову систему, гіпоталамус, гіпофіз, яєчники, матку, гормональний фон та місцеву (клітинну) регуляцію (Ledermann J. А. 2018). Єдиним цілим, в даному випадки, представлені нервова (основна індукувальна) й ендокринна (медіатор) системи. Фізіологічне функціонування репродуктивної системи відбувається за інтегрованого контролю нервових і гуморальних імпульсів. Стероїди впливають на кору головного мозку, яка в свою чергу діє на регуляторні механізми експресії та синтезу статевих гормонів. Кора головного мозку, в свою чергу, впливає на регуляцію репродуктивної функції через гіпоталамус, гіпофріз, і залози внутрішньої секреції. Гіпоталамус, здійснює функції, властиві залозам (синтез рилізинг-факторів), регулюючи, тим самим, фрізіологічні процеси статевих органів через зв'язки з різними відділами нервової системи по нервових провідниках.. Саме гіпоталамус інтегрує інформацію від ЦНС та ендокринних залоз, і перетворює останню в гуморальний сигнал, направляє в гіпофріз (Zhou A. G. 2018).

Такий порядок прямих і зворотних зв'язків, об'єднує всі біохімічні процеси, що перебігають у статевих органах корів під час естрального циклу. Прискорюють ці біохімічні процеси - ферменти, що володіють каталітичними властивостями, й забезпечують об'єднану зв'язність обмінних процесів. На реструктуризацію ендометрія, яєчників, і синтез статевих гормонів витрачається величезна кількість енергії, активуючи тим самим енергообмін. (Seba M. V. 2016.)

Першорядне джерело утворення енергії в клітині це гліколіз. Останній фермент гліколіза- лактатдегідроге- наза, оскільки саме ЛДГ каталізує зворотне відновлення пірувату до лактату. ЛДГ, як відомо, гліколітичний цинкмісткий фермент-маркер гліколізу (Abdisa, T. 2018).

Всі тканини організму мають різну швидкість метаболізму, енергетичні потреби й функції, які досить часто висвітлює активність ЛДГ. По мірі проходження клітин через клітинний цикл, експресія лактатдегідрогенази значно коливається. Дослідники з'ясували, що інтенсивність експресії лактатдегідрогеназа достовірно збільшується під час активації та проліферації тканин. Цей фракт дозволяє використовувати ДЛГ в якості маркеру проліферації. Достовірне зниження активності лактатдегідрогенази реєстрували під час стану «спокою» клітини. Саме через це ДЛГ використовують не тільки як маркер проліферації, й і в якості маркеру мобілізації клітин. (Rong Y, 2013)

При патологічних станах, які супроводжуються кисневою нестачею, та за хронічного впливу стрес-фактору, енергетичне забезпечення клітин компенсується активацією анаеробного гліколізу із зростанням рівня лактатдегідрогенази. При пластично-ремодулювальних та патологічних процесах ендометрія, аеробний гліколіз замінюється на анаеробний, активуючи при цьому LDH. Остання обумовлює накопичення недоокислених продуктів і використання глікогену та глюкози для забезпечення енергетичних потреб клітин ендометрія (Eremenko V.Y. 2017).

Фізіологічне підвищення активності ЛДГ реєструється при інтенсивних фрізичних навантаженнях, у новонароджених та вагітних, тобто за умов активації та проліферації клітин. Захворювання, що супроводжуються пошкодженням тканин та клітин, також супроводжуються підвищенням рівня ЛДГ. В зв'язку з цим лактатдегідрогеназа, це важливий маркер проліферації та мобілізації клітин, а також показник тканинної деструкції. Таким чином, дослідження вмісту лактатдегідрогенази в тканинних екстрактах ендометрія протягом різних стадій статевого циклу, та за постморбідного стану, є інформативним у питаннях відновлення та корекції відтворної здатності корів (Kupyna A.D. 2019).

Аналіз основних досліджень і публікацій.

Ендометрій - оболонка матки, яка знаходиться в стані постійної ротації протягом естрального циклу, імплантації та вагітності. Це орган-мішень для статевих гормонів, чутливість до яких проявляється лише за наявності специфічних рецепторів. Останній перебуває в стероїдозалежному стані рецептивності протягом саморегульованого періоду, під час якого й відбувається адгезія бластоцисти на його поверхні. (Bondarenko I. V. 2019).

Підготовка ендометрія до нідації - важлива передумова фрізіологічної вагітності. Проліферативна активність функціонального шару ендометрія, залежить від гормонального впливу та наявності відповідних рецепторів у клітинах-мішенях гормонозалежної тканини. Фізіологічність імплантації та ембріогенезу забезпечує оптимальне середовище матки, а також адекватна реакція рецепторного апарату ендометрія на статеві гормони, оскільки нидація зародку неможлива на ділянці нерецептивного ендометрія. Взагалі, імплантація можлива тільки за стану рецептивності ендометрія, тобто, здатності 
прийняти бластоцисту. Рецептивніст ендометрія, це комплекс його структурно-функціональних характеристик, які визначають здатність до імплантації. За розвитку анатомо-фрізіологічних розладів вищеозначеної складової статевого апарату самки, в порожнині матки активується процес утворення фібробластів та апоптозу функціонального шару. Ці процеси обумовлюють зниження сприйнятливості рецепторного апарату, й викликають непліддя (Kolmyk V. A. 2016).

Під впливом негативних санітарно-гігієнічних факторів, виникає гормональний дисбаланс між рівнем гонадальних та гонадотропних гормонів, що в свою чергу обумовлює розлади гіпоталамо-гіпофрізарної системи. Дисбаланс між гонадальними та гонадотропними гормонами провокує ланцюг фрункціональних порушень й прояв неповноцінного статевого циклу, або взагалі анафродизію (Vasylenko, T.F. 2007).

За хронічного стресу, що виникає в невідповідних санітарно-гігієнічних умовах утримання, годівлі та експлуатації, формуються стійкі нейроендокринні й нейрогуморальні розлади гіпофізарно-оваріально-маткової системи, клінічний прояв яких характеризується порушенням статевої циклічності. Формується замкнена патологічна система, в якій з одного боку знижується активність залоз внутрішньої секреції, й гальмується синтез гормонів; з другого, погіршується здатність інактивування статевих гормонів. Таке порушення гормональної взаємодії в організмі також обумовлює розвиток анафродизії. (Kolmyk V.A. 2016).

Досягнення науковців в галузі гормональної регуляції відтворної функції корів, мають значення лише за умов повноцінних годівлі та утримання. Годівля впливає на відтворну здатність тварини набагато сильніше, ніж породні, видові, гендерні чи інші чинники. Усі погрішності годівлі та утримання, особливо тварин з високою продуктивністю, ведуть до порушення обміну речовин, розладів роботи шлунково-кишкового тракту, пригнічення резистентності та до виникнення імунодефіциту, й обумовлюють включення механізмів саморегуляції відтворення. Незбалансованість годівлі за енергетичною цінністю, змінює загальний метаболізм та спотворює функції окремих систем і органів, й негативно впливає на відтворення. Однаково небезпечні як виснаження так і ожиріння. Незбалансованість раціонів щодо вмісту вітамінів, макро- та мікроелементів, також обумовлюють непліддя. Загальновідомо, що застосування раціонів які містять уві необхідні поживні речовини та вітаміни, це найкраща стимуляція статевої функції. Саме повноцінні раціони створюють в організмі корови певні умови, які дають можливість правильно й чітко здійснювати всі фрізіологічні нервово-рефлекторні процеси (Khamytova L. F. 2015).

Взагалі, енергетичний баланс організму корови, залежить від кількості та якості отриманого корму, й до 30- 40 доби після родів, він негативний, оскільки в матці триває інволюція. На фоні високої продуктивності, негативний енергетичний баланс в цей період, викликає зниження активності ремодуляційних процесів ендометрія. Хронічний стрес спотворює сигнали гіпоталамуса та гіпофіза, й як наслідок - синтез гонадотропних гормонів і прояв повноцінної стадії збудження (Leibova V.B. I2018). Розлади раціону на фоні неповноцінних санітарно-гігієнічних фракторів, підвищують навантаження на детоксикаційно-бар'єрну систему й сприяють розвитку екологічної дезадаптації організму. На невизначений термін репродуктивна система послабляє чи взагалі припиняє свою фрнкцію, й не бере участі в адаптаційних механізмах організму, забезпечуючи ресурсами життєво важливі функції. Розвивається хронічна оваріальна недостатність, порушення гормонального гомеостазу матки, й як наслідок - розлади циклічної трансформації ендометрія. Саме це зумовлює необхідність вивчення та обґрунтування комплексної оцінки фрунціонального шару ендометрія протягом різних стадій статевого циклу та за постморбідного стану. (Khamytova L. F. 2015; Bondarenko I. V. 2019)

Науковці довели, що продукування статевих гормонів модулюється гонадотропінами та факторами росту, а сам стероїдогенез залежить від чисельних складових таких як: рівень кисню в клітинах статевих органів, концентрація гонадотропних гормонів, ступінь зрілості клітини, присутність субстратів окиснення, та багатьох інших. Взагалі кількість статевих гормонів залежить від вмісту кисню в клітинах, оскільки останні використовують субстрати під час окисного метаболізму, нагромаджують і утилізують цитотоксичні продукти Оксигену. Одним з маркерів-ензимів, спроможним визначати інтенсивність вживання глюкози й постачання субстратів в клітини - є лактатдегідрогеназа. (Bodnar Yu. V. 2015).

У лактатдегідрогенази $€$ п'ять ізоферментів, що володіють різною тканинною специфічністю. ЛДГ1 та ЛДГ2 мають високий ступень спорідненості до молочної кислоти, та навпаки, низький до пірувату. Клітини в яких переважають вищезгадані ізоформи, в тому числі й ендометрій, мають переважно аеробним шлях окислення глюкози . Якщо в клітини потрапляє молочна кислота, то ЛДГ1 та ЛДГ2 окислюють її до пірувата, який через піруватдегідрогеназний комплекс спрямовується на цикл Кребса. При інтенсивних та енергозатратних процесах у тканинах, наприклад при ремоделюванні ендометрія, вмикається анаеробний метаболізм глюкози. Тому визначення активності лактатдегідрогенази допомагає з'ясувати метаболічну активність окремих тканин. Для цієї мети проводять визначення загальної сироваткової активності ЛДГ сумісно з активністю гідроксибутиратдегідрогенази (ГБДГ). Доведено, що до альфа-гідроксімасляноїй кислоти виявляють спорідненість лише ізоформи - ЛДГ1 та ЛДГ2. Тому за активністю реакції окислення альфа-гідроксибутирата до альфа-оксобутирата можливо з'ясувати процент включення ЛДГ1 та ЛДГ2 в загальну лактатдегідрогеназну активність (Tamboli P. 2000).

Таким чином, при інтенсивних та енергозатратних процесах у тканинах активуються ізоформи ЛДГ, які відповідають за відновлення пірувату в лактат, що свідчить про одночасну активацію аеробного та анаеробного окислення глюкози. Очевидно, активація найменш енергетично раціонального анаеробного метаболізму протягом ремоделювання ендометрія, е тимчасовою, компен- 
саторною мірою, й може бути маркером напруженості метаболізму в цілому (Leibova V.B. 2018.).

Для всебічної оцінки процесу гліколізу, науковці досліджували активність лактатдегідрогенази, вміст якої інформативно змінюється протягом статевого циклу. Лактатдегідрогеназа міститься у всіх тканинах організму, де її концентрація набагато вища за сироватку крові. Сучасні наукові дослідження частково висвітлюють молекулярні механізми контролю регулювання гомеостазу тканинного обміну ендометрія, звертаючи увагу на активацію енергетичних процесів клітин, в тому числі й на пригнічення анаеробного гліколізу. За умов функціональних розладів проліферативних процесів ендометрія, які унеможливлювали імплантацію, рівень активності ЛДГ знижується (Rong Y, 2013).

На початку стадії збудження (феномени тічки та загальної реакції), за реєпітелізації функціонального шару ендометрія (проліферативна фаза), активується анаеробний гліколіз, що супроводжується зростанням вмісту лактатдегідрогенази. ЛДГ в цей час локалізується в цитоплазмі клітин залозистого епітелію, на відміну від клітин строми, де реєструється незначний вміст останньої (V.B. Leibova, 2018.).

Протягом стадії збудження, особливо за феноменів охоти та овуляції, відбувається достовірне зростання LDH, за рахунок активації цитохімічних процесів вуглеводного обміну, що обумовлює створення сприятливого для перебігу вагітності внутрішньоматкового середовища. В цей час реєструється найвища активність ЛДГ як в клітинах залозистого епітелію, так і в клітинах строми ( Zhou A. G. 2018.).

За стадії гальмування, відбувається унікальний процес реконструкції ендометрія. Так, циклічна інволюція функціонального шару (часткове відторгнення ендометрія), що виникає в результаті дезінтеграції клітин функціонального шару, проходить одночасно з реєпітелізацією (регенерацією) ендометрія. Протягом стадії гальмування та на початку стадії врівноваження (активується аеробний гліколіз), локалізація ЛДг реєструється в апікальних відділах залозистих клітин ендометрія, а кількісний її показник зменшується (Bondarenko I. V. 2019).

На нашу думку зміна активності лактатдегідрогенази за різного стану статевої функції, без сумніву є маркером функціонального стану ендометрія. Проте її роль в формуванні стадій статевого циклу повністю не розкрита й потребує подальшого вивчення.

Мета досліджень. Задачею наших досліджень було визначити й проаналізувати зміни вмісту LDH у тканинних екстрактах фрнкціонального шару ендометрія маточного поголів'я корів під час різних стадій статевого циклу за анафродизії в порівняльному аспекті.

Матеріал і методика дослідження.

Дослідження проводились в наступних господарствах: за прив'язного утримання 3 продуктивністю <6000кг: ВАТ П3 «Михайлівка» Лебединського району Сумської області (корови швіцької породи), СФГ «Віталія» Буринського району Сумської області (корови симентальської породи), за безприв'язного утримання з продуктивністю >6000кг: ТОВ АФ "Владана" (корови української чорнорябої породи), та ТОВ АФ "Лан" Сумського району Сумської області (корови голштинської породи).

Матеріалом для досліджень були фрагменти слизової оболонки матки, відібрані від вимушено забитих корів без патологічних змін репродуктивної системи віком 3-10 років, під час еструсу $(n=5)$, розквіту жовтого тіла $(n=5)$, передбачуваної тічки $(n=5)$ та в клінічно здорових корів, що не проявляли статеву циклічність після перехворювання на ендометрит ( $n=5)$ і затримку посліду $(n=5)$.

Зразки ендометрія (3-5 г) відбирали в ділянці верхньої третини рогу матки. Для визначення вмісту LDH в тканинних екстрактах, фрагменти слизової оболонки матки, відмивали у фрізіологічному розчині та піддавали кріоконсервації в пластикових мікропробірках при - 20॰С. 3 отриманих зразків ендометрію готували тканинні екстракти із використанням 0,5 н розчину $\mathrm{NaOH}$ (Slutskyi L.Y.1969). Надалі гомогенат тканин центрифугували при 3000 об/хв. протягом 15 хв. У надосадовій рідині визначали вміст лактатдегідрогенази (LDH) у реакції з 2,4-динітрофенилгідразином за методом СевелаТоварека. Отриманий цифровий матеріал оброблено методами варіаційної статистики із використанням параметричного t-критерію Стьюдента.

Результати досліджень висвітлюють значення вмісту LDH в слизовій оболонці матки під час еструсу, розквіту жовтого тіла, передбачуваної тічки та за анафродизії, й можуть бути використані при виборі та обґрунтуванні методів корекції статевої циклічності корів.

Результати досліджень. Отримані дані наведені в таблиці та продовженні таблиці 1.

Дані, що ми отримали під час досліджень, також наведені на рисунках 1 та 2.

Вміст LDH у тканинних екстрактах функціонального шару ендометрія під час охоти (рис 1.) був вірогідно вищім на 18,1\% ( $\mathrm{P}<0,013)$ порівняно з 7-8 добою статевого циклу (розквіт жовтого тіла), та на 12,5\% ( $\mathrm{P}<0,043)$ в тварин з передбачуваним проеструсом на 17-18 добу статевого циклу, відповідно, що свідчить про реєпітелізацію функціонального шару ендометрія за активації анаеробного гліколізу.

До 17-18 доби статевого циклу реєструється помітна активація процесів анаеробного гліколізу функціонального шару ендометрія, що супроводжується недостовірним зростання вмісту LDH тканинних екстрактів, майже на $11 \%$ порівняно з 7-8 добою статевого циклу. Очевидно, підвищення вмісту лактатдегідрогенази у тканинних екстрактах функціонального шару ендометрія пояснюється початком реєпітелізації та проліферативно - функціональною перебудовою ендометрія (Bondarenko I. V. 2016).

Отже, динаміка концентрації лактатдегідрогенази у тканинних екстрактах функціонального шару ендометрія корів, деталізує процес активації анаеробного гліколізу, протягом фрізіологічного ремоделювання ендометрію та відображає його функціональну активність за різних стадій статевого циклу (Bondarenko I. V. 2019).

Дані, приведені на рисунку 2, свідчать про те, що вміст лактатдегідрогенази в тканинних екстрактах функціонального шару ендометрія корів, що перехворіли на 
Вміст лактатдегідрогенази в тканинних екстрактах функціонального шару ендометрія за різних стадій статевого циклу та при анафродизії корів

\begin{tabular}{|c|c|c|c|c|c|c|c|c|c|c|}
\hline \multirow[b]{2}{*}{ Показники } & \multicolumn{3}{|c|}{ Клінічно здорові } & \multicolumn{2}{|c|}{$\begin{array}{c}\text { Тварини, } \\
\text { що перехворіли на: }\end{array}$} & \multirow[b]{2}{*}{$\mathrm{P} 1<$} & \multirow[b]{2}{*}{$\mathrm{P} 2<$} & \multirow[b]{2}{*}{ P3< } & \multirow[b]{2}{*}{$\mathrm{P} 4<$} & \multirow[b]{2}{*}{ P5< } \\
\hline & $\begin{array}{c}\text { охота } \\
\text { (рефлекс } \\
\text { нерухомості) } \\
\text { n=5 }\end{array}$ & $\begin{array}{c}\text { 7-8 доба ст. } \\
\text { цик. (розквіт } \\
\text { жовт тіла) } \\
\text { n=5 }\end{array}$ & $\begin{array}{c}\text { 17-18 доба } \\
\text { ст. циклу } \\
\text { (проеструс) } \\
\text { n=5 }\end{array}$ & $\begin{array}{c}\text { ендометрит, } \\
n=5\end{array}$ & $\begin{array}{c}\text { затримку } \\
\text { посліду, n=5 }\end{array}$ & & & & & \\
\hline $\begin{array}{c}\text { лактатдегідро- } \\
\text { геназа од/л }\end{array}$ & $12504 \pm 566,4$ & $10584 \pm 199$ & $11060 \pm 195$ & $11378 \pm 151,4$ & $10371 \pm 445,7$ & 0,013 & 0,043 & н.Д. & 0,05 & 0,017 \\
\hline
\end{tabular}

Примітки:

P1- 0 день стат. цик. порівняно із 7-8 днем ст. цик.;

P2- 0 день стат. цик. порівняно з 17-18 днем ст. цик.;

Р3 -7-8 днем ст. цик. порівняно з 17-18 днем ст. цик.;

P4 -0 день стат. цик. порівняно клінічно здоровими тваринами, що перехворіли на ендометрит;

P5- 0 день стат. цик. порівняно з клінічно здорові тварини, яка перехворіли на затримку посліду.

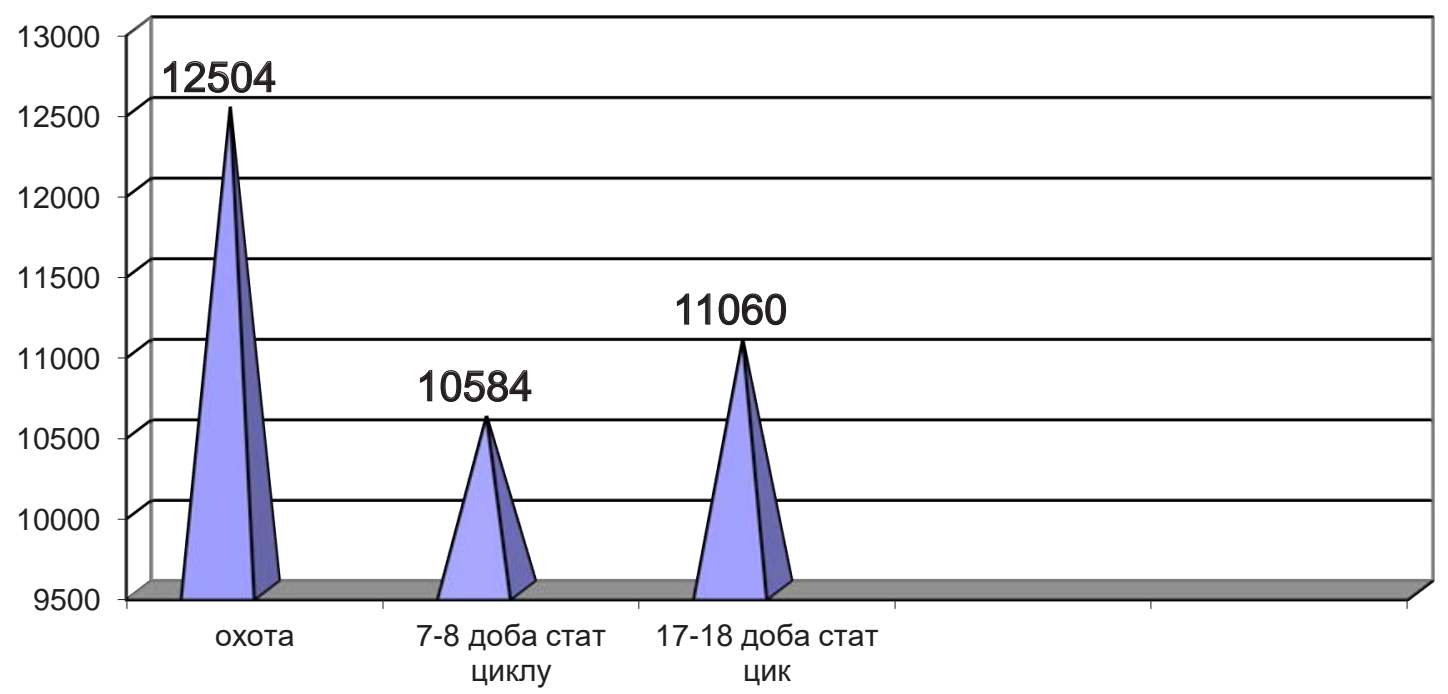

Рис. 1. Вміст лактатдегідрогенази у тканинних екстрактах фрункціонального шару ендометрія корів, відносно стадій статевого циклу, (Од/л)

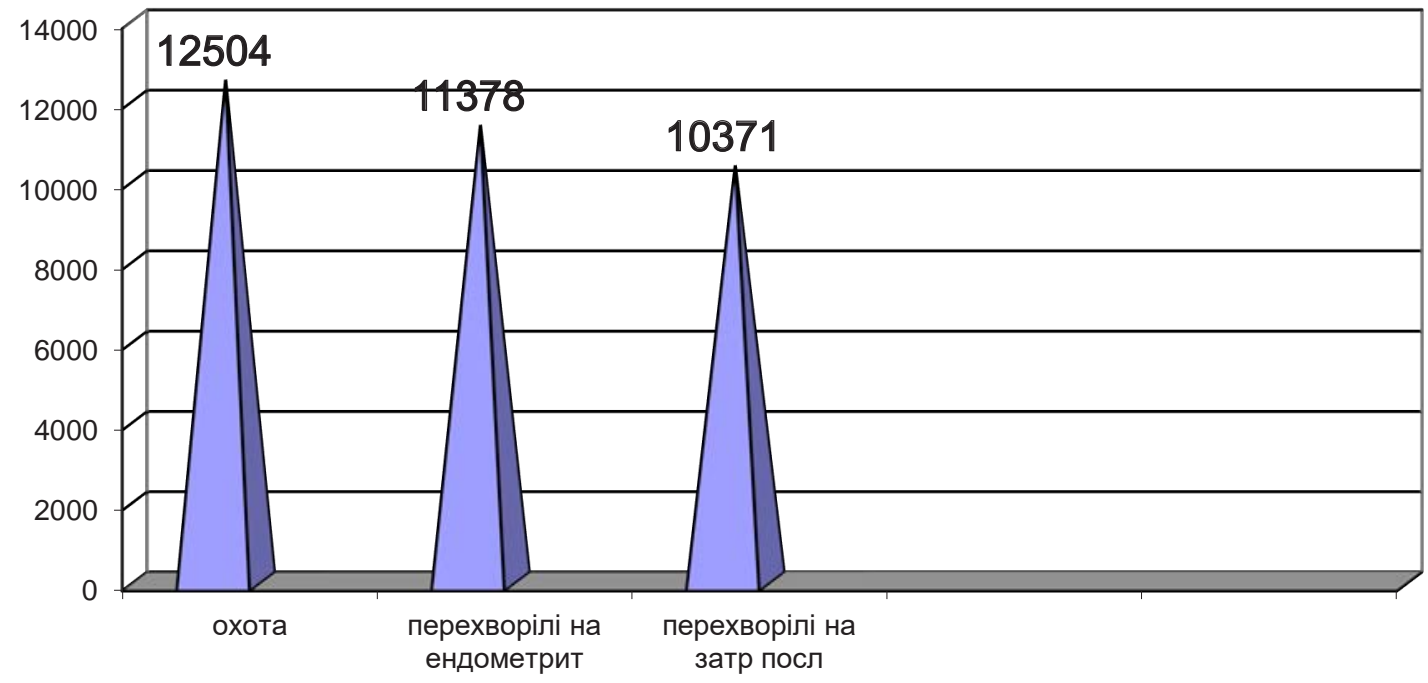

Рис. 2. Вміст лактатдегідрогенази тканинних екстрактах функціонального шару ендометрія корів, відносно стану статевої функції, (Од/л) 
ендометрит та затримання посліду, був вірогідно нижчим майже на 9,8\% $(P<0,05)$ та 12,4\% ( $<<0,017)$ відповідно, за рівень ЛДг корів в охоті. Це, на нашу думку, можна пояснити суттєвим пригніченням метаболічної та секреторної активності ендометрія за постморбідного стану, оскільки при функціональних розладах реєпітелізації та проліферативно - функціональної перебудови ендометрія, рівень активності ЛДГ знижується.

Підтверджують даний висновок і наші попередні дослідження вмісту лактатдегідрогенази в сироватці крові корів, відносно різних стадій статевого циклу та стану статевої функції (Parashchenko I.V. 2011).

Нами було з'ясовано, що в плазмі крові корів за постморбідного стану реєструється суттєве зниження рівня сполучнотканинних маркерів: лактатдегідрогенази, глікопротеїнів та глікозаміногліканів. На нашу думку, це пов'язано з пригніченням анаеробного гліколізу, що супроводжується зменшенням вмісту лактатдегідрогенази, та гальмуванням утворення залозистого секрету збагаченого білково-вуглеводними комплексами, через недостатність функціональної активності залоз ендометрія (V.B. Leibova 2018; Bodnar Yu. V. 2015).

Висновки та перспективи подальших досліджень.

1. Порівняно з іншими феноменами та стадіями статевого циклу корів, під час охоти реєструється максимальне зростання концентрації лактатдегідрогенази в тканинних екстрактах ендометрія, за рахунок активації фрункціональної активності, й переважання анаеробного гліколізу.

2. У корів в стані анафродизії, що перехворіли на ендометрит і затримання посліду, рівень лактатдегідрогенази в тканинних екстрактах ендометрія був достовірно нижчим порівняно з показником статевої охоти. Ймовірно, це пов'язано з пригніченням метаболічної та секреторної активності функціонального шару ендометрія за постморбідного стану.

Перспективою подальших досліджень $€$ необхідність з'ясування ролі лактатдегідрогенази за анафродизії корів, що перехворіли на ендометрит і затримання посліду, та опрацюванні обґрунтованих методів корекції.

\section{References}

1. Sheremeta V. I., Sapiga O. A. (2009). Reproductive ability of sows when using biologically active drugs. Sci Bull NUB\&NU of Ukraine.; 136: 210-4.

2. Shtapenko O. V., Gevkan, I. I., Shtapenko, O. V., Sluvchyk, Yu. I., Dzen`, Ye. O., Syrvatka, V. Y., Matvienko N. M. (2018). Effect of organic microelements liposomal form on fertilizing ability and antioxidant status of female rabbits. Biotechnologia Acta. 11, 4: 50-56.

3. Bezverha LM, Sheremeta VI. (2012). Reproductive ability of sows when using biologically active drugs. Sci Bull NUB\&NU of Ukraine. Part 1, 72 (4): 68-72.

4. Tvarynnytstvo ta veterynariya (Spetsial'nyy vypusk «Abetka vidtvorennya») [Livestock and Veterinary Medicine (Special issue "Reproduction Abbey")] (2018). - Kyiv, 555 [in Ukrainian].

5. Sheremeta VI, Bezverha LM. (2011). Fertility of Large White breed sows when using biologically active products. Proceedings of Vinnytsia national agrarian University. 8 (48): 84-8.

6. Vasylenko, T.F., Chermnykh, N.A., Roshchevskyi T.F. (2007). Fyzyolohyia reproduktyvnoi funktsyy u samok dykykh y domashnykh zhvachnykh zhyvotnykh. [Physiology of reproductive organs of female wild and domestic animals]. XX Sezd Fyzyolohycheskoho obshchestva ymeny Y.P.Pavlova: Tezysы dokladov, 22. [in Russian].

7. Riordan, N. H., Morales, I., Fernández, G., Allen, N., Fearnot, N. E., Leckrone, M. E., et al. (2018). Clinical feasibility of umbilical cord tissue-derived mesenchymal stem cells in the treatment of multiple sclerosis. J. Transl. Med. 16:57. doi: 10.1186/s12967-018-1433-7.

8. Bondarenko I., Lazorenko, A., \& Krajewsky, A. (2019). Structural and morphological changes of endometrium related to ovary cycle and condition of genital function of cows. Bulletin of Sumy National Agrarian University. The Series: Veterinary Medicine, (3 (46), 9-22. https://doi.org/10.32845/bsnau.vet.2019.3.2

9. Parashchenko I.V. (2011). Dynamika heksoz spoluchenykh iz bilkom, hlikozaminohlikaniv ta hlikoproteiniv u plazmi krovi koriv za riznykh stadii statevoho tsyklu ta stanu statevoi funktsii. Visnyk Sumsk. natsion. ahrar. un-tu. 2 (29), 116-119 (in Ukrainian).

10. Bondarenko I. V. (2016). Zminy vmistu bilkovo-vuhlevodnykh polimeriv u funktsionalnomu shari endometriia koriv zalezhno vid stadii statevoho tsyklu ta stanu statevoi funktsii. Visnyk Sumskoho natsionalnoho ahrarnoho universytetu. Veterynarna medytsyna. 11, 180-185 [in Ukrainian].

11.Granot I, Gnainsky Y, Dekel N. (2012). Endometrial inflammation and effect on implantation improvement and pregnancy outcome. Reproduction. 144(6) : 661-8. doi: 10.1530/REP-12-0217.

12. Makrigiannakis A, Makrygiannakis F, Vrekoussis T. (2021). Approaches to Improve Endometrial Receptivity in Case of Repeated Implantation Failures. Front Cell Dev Biol. 9:613277. doi: 10.3389/fcell.2021.613277.

13. Tuckerman E, Mariee N, Prakash A, Li TC, Laird S.J (2010). Uterine natural killer cells in peri-implantation endometrium from women with repeated implantation failure after IVF. Reprod Immunol.87(1-2):60-6. doi: 10.1016/j.jri.2010.07.001.

14. Edwards RG. (2006). Human implantation: the last barrier in assisted reproduction technologies. Reprod Bio Med Online;13:887-904. doi: 10.1016/S1472-6483(10)61039-5.

15. Tamboli P., Ro J.Y., Amin M.B. et al. (2000). Benign tumors and tumor-like lesions of the adult kidney. Part II: Benign mesenchymal and mixed neoplasms, and tumor-like lesions. Adv. Anat. Pathol.. 7, 1, 47-66.

16. Kupyna A.D., Petrov Yu.A., Shatalov A.E. (2019). Sovremennye predstavlenyia o mekhanyzme deistvyia vnutrymatochnykh kontratseptyvov [Modern thinks about intrauterus contraceptors' using]. Zdorove y obrazovanye v XXI veke. [Health and education in XXI century], 8. https://cyberleninka.ru/article/n/sovremennye-predstavleniyao-mehanizme-deystviya-vnutrimatochnyh-kontratseptivov (data obrashchenyia: 21.04.2021). [in Russian]. 
17. Eromenko V.Y., Karpenkova K.V. (2017). Fermentatyvnyi profyl krovy u tyolochek, poluchennykh ot raznoproduktyvnykh korov. Vestnyk Kurskoi hosudarstvennoi selskokhoziaistvennoi akademyy. 4. https://cyberleninka.ru/article/n/fermentativnyyprofil-krovi-u-tyolochek-poluchennyh-ot-raznoproduktivnyh-korov (data obrashchenyia: 21.04.2021).

18. Hara R. (2002). Another kasaharavariant alkaline phosphatase in renal cell carcinoma. JAVA. 70, 4, 503-508.

19. Zhou A. G., Levinson K. L., Rosenthal D. L., VandenBussche C. J. (2018). Performance of ovarian cyst fluid fine needle aspiration cytology. Cancer Cytopathol. 126 (2), 112-121.

20. Ledermann J. A., Raja F. A., Fotopoulou C. et al. (2018). Newly diagnosed and relapsed epithelial ovarian carcinoma: ESMO Clinical Practice Guidelines for diagnosis, treatment and follow-up. Ann Oncol. 29, 4. 259.

21. Moiseeva, K., Vasileva, S., Karpenko L. (2018). Dynamics of sex hormones in cows with different milk production at the beginning of lactation Reproduction in Domestic Animals. 54. S3. 122.

22. Leibova, V.B., Shapiev, I.Sh., Nikitkina E.V. (2018). Biochemical status of cows in the dry period in connection with reproductive performance and milk productivity. Reproduction in Domestic Animals. 53, S2. 157-158.

23. Rong Y, Chen L, Zhu T, Song Y, Yu M, Shan Z, Sands A, Hu FB, Liu L. (2013). Egg consumption and risk of coronary heart disease and stroke: dose-response meta-analysis of prospective cohort studies. BMJ. Jan 7;346:e8539. doi: 10.1136/ bmj.e8539.

24, Seba M. V., Deineka M. O., Khomenko M. O., Kaplunenko V. H. (2016). Zaplidnennia ukrainskykh chorno-riabykh molochnykh koriv. [Insemination of Ukrainian black-white milking cows]. Tvarynnytstvo Ukrainy. [Livestock of Ukraine], 1-2. 19-21. [in Ukrainian].

25. Abdisa, T. (2018). Review on the reproductive health problem of dairy cattle. J Dairy and Vet. Sci, 5(1), 1- 12. doi: 10.19080/JDVS.2018.05.555655.

26. Kolmyk V. A., Nasyrov R. A., Kutusheva H. F., Petrov V. V., Hryhorev S. H. (2016). Znachenye ymmunohystokhymycheskoho kontrolia dlia lechenyia patsyentok s khronycheskym эndometrytom. Pedyatr.3.

27. Khamytova L. F., Merzliakova E. A., MetliakovaA. A. (2015). Problemy vosproyzvodstva stada [Reproductive problems of the herd]. Uchenye zapysky KHAVM ym. Baumana. [Scientific notes of vet academy], 2 URL: https://cyberleninka.ru/ article/n/problemy-vosproizvodstva-stada. [in Russian].

28. Bodnar Yu. V. (2015). Vmist zahalnoho proteinu u kulturi klityn hranulozy [Contaning of common protein in granuloza cell culture] Biolohiia tvaryn. [Animal biology], 17, 3, 150. [in Ukrainian].

29. Slutskyi L.Y. (1969). Byokhymyia normalnoi y patolohychesky yzmenennoi soedynytelnoi tkany. [Biochemistry of normal and pathological connective tissue]. Medytsyna. [Medicine] 376. [in Russian].

\section{Bondarenko Irina, Sumy National Agrarian University (Sumy, Ukraine) \\ Content of lactatedehydrogenase in tissue extracts of functional layer in relation to the stage of sexual cycle and state of sexual function of cows}

Cattle reproduction is a complex set of biological and technological processes that depend on the interaction of external and internal factors. The state of reproduction of cows - is the main problem of dairy farming and characterizes the economic efficiency of livestock in general. Assessment of reproduction in the farm is carried out according to many criteria, which include: the duration of pregnancy, dry, interstitial and service period periods. It is well known that high reproduction rates are not only the basis for reproduction, but also a prerequisite for maximum milk productivity of cows and their long reproductive existence.

The solution of this scientific problem was carried out by using modern biotechnological research methods on different model systems, which allowed to determine the course of gametogenesis in females and males, implantation capacity and features of embryogenesis of mammals caused by the influence of exogenous factors and to develop methods for activating the implantation and embryonic capacity of females.

Profitability of suckling stock-raising depends on effective introduction systematic application of modern reproductive methods of correction, that allow substantially to promote the amount of population, improve genetic potential of highperformance animals, and plan their recreation. A necessary condition of permanent profitability of suckling stock-raising is approbation and practical application of modern methods of stimulation and correction. Exactly the last stipulate an increase to the percent of the impregnated females, minimize the amount of abortions and assist the receipt of healthy issue. Therefore the questions of correction and stimulation of reproductive ability remain actual to this day, and need a complex study and analysis of morpho-physiological features of preparation of the sexual system of cows to the impregnation, implantation and pregnancy. Physiology of impregnation, development of zygotes, and pregnancies, first of all depend on balanced of hormonal background of maternal organism. Stimulation of reproductive potential of cows змушye specialists to the search and wide consumption biologically active substances, tissue preparations and biotechnological events, that activate the metabolic and endocrine systems, and strengthen the exchange processes of genital organs. At the decision of foregoing questions, primary attention is spared to the state of ендометрія for pregnancies of cows, while a process of remodeling of functional layer of endometrium is during the stage of excitation, that provides physiology of implantation and pregnancy, remains out of eyeshot. Optimal hormonal status of organism of cows, predetermines physiology exchange of substances, assists functional activity of genitalia, that provides the receipt of the best indexes of recreation in turn. For effective application of stimulant biologically-active facilities on the reproductive function of cows during the different stages.

The reproductive function is represented by self-regulating and repetitive conversion order, (nerve and humoral chains), which ensures the effectiveness of the adaptive and adaptive effect. This is how the main biological purpose of the reproductive system is achieved - the preservation of the species. Biochemical and morphological changes in the endometrium during different stages of the sexual cycle are accompanied by its physiological restructuring. For chronic stress that occurs in inappropriate sanitary and hygienic conditions, maintenance, feeding and exploitation, are formed by stable neuroendocrine and neurohumoral disorders of the pituitary-ovarian-ovarian system, the clinical manifestation of which is characterized 
by a violation of sexual cyclicality. Chronic stress distorts the signals of the hypothalamus and the pituitary gland, and as a result - the synthesis of gonadotropic hormones and a manifestation of a full-fledged excitation stage. In an indefinite period, the reproductive system weakens or does not terminate its function in general, and does not participate in the adaptive mechanisms of the body, providing resources vital functions. Chronic ovarian insufficiency develops, violation of hormonal homeostasis of the uterus, and as a result - disorders of the cyclic transformation of the endometrium.

It is well-known that the primary source of energy formation in the cell is glycolysis. In pathological conditions, which are accompanied by an oxygen shortage, and for the chronic effects of stress factor, the energy supply of cells is compensated by the activation of anaerobic glycolysis with an increase in lactate dehydrogenase. $\mathrm{LDH}$, as you know, a glycolytic zincglycous glycolysis marker. In plastic-remoder and pathological processes of endometrium, aerobic glycolysis is replaced by anaerobic, activating $\mathrm{LDH}$. The latter causes the accumulation of underoxified products and the use of glycogen and glucose to provide energy needs of the endometrial cells.

The physiological increase in activity of $L D H$ is recorded with intensive physical activity, newborns and pregnant women, that is, under the conditions of activation and proliferation of cells. Diseases accompanied by damage to tissues and cells are also accompanied by an increase in LDG. In this regard, lactate dehydrogenase is an important marker of proliferation and mobilization of cells, as well as an indicator of tissue destruction. Thus, the study of the content of lactate dehydrogenase in tissue endometrial extracts during various stages of the sexual cycle, and for a postmorbid state, is informative in restoration and correction of the reproducible capacity of cows.

For a comprehensive assessment of glycolysis process, scientists investigated the activity of lactate dehydrogenase, whose content is informative during the sexual cycle. Lactate dehydrogenase is contained in all tissues of the organism, where its concentration is much higher than blood serum. Modern scientific researches are partially illuminating molecular mechanisms for controlling the gomeostasis of the tissue exchange of endometrium, drawing attention to the activation of energy processes of cells, including inhibition of anaerobic glycolysis. Under the conditions of functional disorders of the proliferative processes of the endometrium, which permeable implantation, the level of activity of LDH is reduced.

At the beginning of the excitation stage (phenomena of tricks and general reactions), for the registration of the functional layer of the endometrium (proliferative phase), anaerobic glycolysis is activated, which is accompanied by an increase in the content of lactate dehydrogenase. LDH at this time is localized in the cytoplasm of the cells of the glandular epithelium, in contrast to the cells of the stroma, which records a slight content of the latter.

During the stage of excitation, especially for the phenomenon of hunting and ovulation, there is a significant increase in $\mathrm{LDH}$, due to the activation of cytochemical processes of carbohydrate metabolism, which determines the creation of a favorable pregnancy in the intrauterine environment. At this time, the highest activity of the LDG both in the cells of the glandular epithelium and in the cells of the stroma is recorded.

In the article results over of research of concentration of Lactatedehydrogenase are brought and analysed in the tissue extracts of functional layer of endometrium of cows at the different stages of sexual cycle and after anafrodisia. It is set that during ecmpycy there is the most active physiology activation of metabolism that is accompanied by the increase of concentration of лактатдегідрогенази in the extracts of fabrics of endometrium, comparatively with проеструсом and at the bloom of yellow body. For animals that had had on endometritis and delay of dung, and were in the state of anaphrodisia, the concentration of Lactatedehydrogenase in the tissue extracts of functional layer of endometrium approaches minimum values. The content of $L D H$ in tissue extracts of the functional layer of the endometrial layer during hunting (Fig. 1.) was significantly higher by $18.1 \%$ ( $p<0.013$ ) compared to $7-8$ days of the sexual cycle (a yellow body), and by $12.5 \%(P<0.043)$ in animals with a predictable projection for $17-18$ days of the sexual cycle, respectively, indicating the registration of the functional layer of the endometrium for the activation of anaerobic glycolysis.

By 17-18, the sexual cycle records a noticeable activation of the processes of anaerobic glycolysis of the functional layer of the endometrium, which is accompanied by an unreliable increase in the content of LDH tissue extracts, almost $11 \%$ compared to 7-8 days of the sexual cycle. Obviously, an increase in the content of lactate dehydrogenase in tissue extracts of the functional layer of the endometrium is due to the beginning of registration and proliferative - functional restructuring of endometrium. Consequently, the dynamics of concentration of lactate dehydrogenase in tissue extracts of the functional layer of the endometrial endometrial layer, detailing the activation of anaerobic glycolysis, during physiological remodeling of the endometrium and reflects its functional activity at different stages of the sexual cycle. the content of lactate dehydrogenase in the tissue extracts of the functional layer of the endometrium of cows that relapsed into endometritis and manure retention was probably lower by almost $9.8 \%(P<0.05)$ and $12.4 \%(P<0.017)$, respectively, for the level of $L D H$ in cows in the hunt. This, in our opinion, can be explained by a significant inhibition of metabolic and secretory activity of the endometrium in the postmorbid state, because in functional disorders of repithelialization and proliferative - functional rearrangement of the endometrium, the level of $L D H$ activity decreases.

This conclusion is confirmed by our previous studies of the content of lactate dehydrogenase in the serum of cows, in relation to different stages of the sexual cycle and the state of sexual function. We found that in the blood plasma of cows in the postmorbid state there is a significant decrease in the level of connective tissue markers: lactate dehydrogenase, glycoproteins and glycosaminoglycans. In our opinion, this is due to the inhibition of anaerobic glycolysis, which is accompanied by a decrease in lactate dehydrogenase, and inhibition of the formation of glandular secretion enriched with protein-carbohydrate complexes, due to lack of functional activity of the endometrial glands.

Key words: cows, Lactatedehydrogenase, tissue extracts, endometrium, sexual cycle anaphrodisia. 